\title{
Caribbean society: Elite networks in Suriname
}

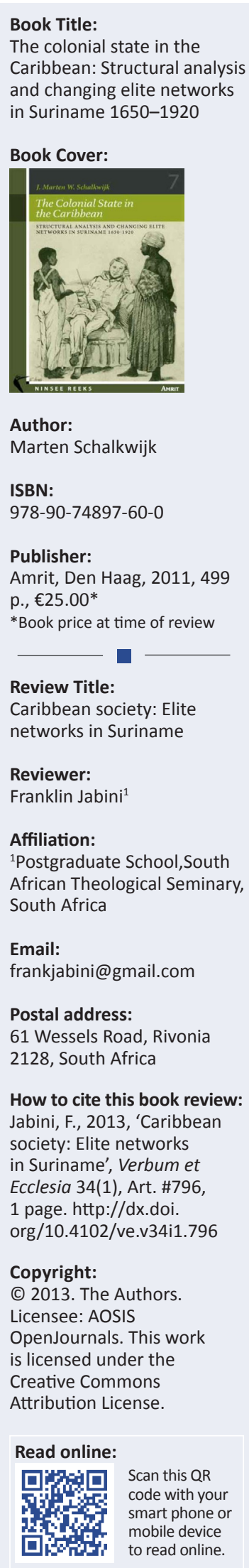

Marten Schalkwijk completed his dissertation in sociology at Cornell University in the United States of America in 1994. Currently he is a professor at the Anton De Kom Universiteit in Suriname. The dissertation was published almost two decades after it was first written.

The dissertation studies five elite networks during five periods of approximately 30 years apart in the history of Suriname (1795, 1830, 1860, 1890 and 1920). The dissertation comprises ten chapters: Chapters 1 to Chapter 3 (pp. 18-131) lay the theoretical foundation of the study. Thereafter the five elite networks are discussed (pp. 132-430): Plantation economy and planters (ch. 4), The coercive nature of plantation society (ch. 5), Colonial constitutions, judges and bureaucrats (ch. 6), Civil society: Religion and voluntary associations (ch. 7) and The body politic: Representation and elite conflict (ch. 8). The work is summarised in Chapter 9 (State-society relations and overall elite structures), which is followed by conclusions in Chapter 10.

The dissertation touches upon an important area in the history of racial and social relationships in Suriname. In his first chapter Schalkwijk sets the stage when he argues that ' $[t]$ owards the 18th century most, if not all, Caribbean societies developed into elite or class societies, with a ruling white minority and a black majority of workers' (p. 18). Amongst the White minority, there was a network of elite groups that dominated the affairs of the whole colony:

At the outset of colonization European feudal organization gave pre-eminence to the owners and their agents. The top planters quickly developed into a new economic and political elite that resembled a Marxian Ruling Class. (p. 456)

An analysis of this topic within the African context may reveal similar conclusions, even after the postcolonial era, with a small group of political or religious loyalists ruling the majority.

Readers of this journal will particularly be interested in Chapter 7, in which Schalkwijk studies religion and voluntary associations in civil society. He concludes for example that in 1831 the social elite was made up of 15 people, headed by the attorney-general, followed by the Reformed and the Lutheran ministers. Each sat on four or more boards of voluntary associations (p. 330). With regard to the religious elite he says:

A more neutral way to draw boundaries of the religious elite is to define all those in the highest religious offices or boards as such. The two top planters in 1830 were Lutherans, while the number three planter was Catholic. (p. 331)

Religious leaders seem to have been very influential in the colonial society. The elite network of a minority left its mark on Surinamese society.

The study has 1920 as its terminus ad quem. This leaves room for follow-up research. In 1948, Suriname was given home rule; it became an independent part of the kingdom of the Netherlands. It gained its independence from the Netherlands in 1975. Between 1980 and 1987 it was ruled by the military, who came to power after a coup. Research investigating how things have changed since the 1920s and whether or not there is a new elite minority would be a fitting continuation of Schalkwijk's work. The publication of this work is a major contribution to the study of Caribbean society. 